\title{
Complete DNA Sequence of Lactococcus lactis Adds Flavor to Genomics
}

\author{
Oscar P. Kuipers \\ Molecular Genetics Group, Groningen Biomolecular Sciences and Biotechnology Institute, University of Groningen, 9750 AA Haren, \\ The Netherlands
}

$\mathbf{W}$ awaited genome sequence of Lactococcus lactis ssp. lactis IL1403, Bolotin et al. (2001) have set the stage for functional and comparative genomics of an important group of industrial microorganisms, that is, the lactic acid bacteria (LAB). LAB are widely used for starting industrial fermentations of milk, vegetables, meat, and fish. L. lactis is used in cheesemaking, as it is involved in casein degradation, in acidification by formation of lactate, and in the formation of flavor compounds. Other LAB, such as Streptococcus thermophilus, Lactobacillus delbrueckii subsp. bulgaricus, and certain Bifidobacteria, are used for yogurt production, whereas Proprionibacteria and other species contribute to the product characteristics of Swiss-type cheeses. $L$. lactis is the major starter for Cheddar production; for a Dutch cheese such as Gouda, a complex starter culture containing $>100$ different strains of LAB is used.

L. lactis is by far the best characterized LAB with respect to its physiology, metabolic pathways, and regulatory mechanisms. The ease of genetic modification of various species of $\mathrm{LAB}$ and the existence of a worldwide network of $\mathrm{LAB}$ researchers have greatly stimulated fundamental and applied research in LAB (Gasson and de Vos 1994; Konings et al. 1999). Industrial applications are directed mainly toward improvement of flavor, texture, and preservation characteristics of fermented products as well as enhancement of industrial robustness of starter cultures. Novel uses of LAB, such as in oral vaccines or in preparation of

E-MAIL o.p.kuipers@biol.rug.nl; FAX 0031 503632348.

Article and publication are at www.genome.org/cgi/ doi/10.1101/gr.188501. functional foods or their direct application as a probiotic culture, are also being explored (Delcour et al. 1999). For oral vaccines, specific antigenic determinants are overproduced either intra- or extracellularly in LAB and subsequently administered orally, nasally, or vaginally to the animal to stimulate mucosal immunity (Gilbert et al. 2000). In situ production of interleukin in mice has already been successful, showing the high potential of LAB for medical applications (Steidler et al. 2000). The main breakthroughs for using $L$. lactis as an improved cell factory were the development of a wide variety of genetic modification tools, highly effective controlled-gene expression systems, novel metabolic engineering strategies, and food-grade cloning systems (Kuipers et al. 2000). In this respect, all requirements are fulfilled to make optimal use of the information to be mined from the lactococcal genome.

The investigators from INRA and Génoscope have used an original approach, comprising diagnostic sequencing followed by a shotgun polishing step. This has resulted in a $2.37-\mathrm{Mb}$ genome sequence, which upon annotation revealed 2310 proteins. The error rate in the final sequence is stated to be $<0.01 \%$. The L. lactis genome was shown to contain quite high numbers of IS elements and prophages (Chopin et al. 2001), as expected from earlier work. It also contains the relatively high number of paralogous genes that are found in, for example, Bacillus subtilis, the first fully sequenced gram-positive bacterium (Kunst et al. 1997). However, only three putative $\sigma$-factors were found in $L$. lactis in contrast to the 18 identified in B. subtilis, which indicates that regulation of expression of many genes is achieved quite differently in both organisms. Moreover, only eight twocomponent regulatory systems (instead of 34 in B. subtilis) were found, indicating that L. lactis may be less wellequipped to adjust to changing environmental conditions, although several mechanisms for dealing with stress have been described (Rallu et al. 2000). Actually, $L$. lactis resides in a much more stable nutritional environment than does B. subtilis, obviating the need for an extensive adaptation machinery.

A particularly interesting feature in the annotated sequence is the occurrence of genes usually related to competence, that is, the natural ability to take up DNA from the environment. Unlike the situation in B. subtilis, all latecompetence genes in L. lactis possess leaderless mRNAs, indicating a quite different type of regulation of their expression. It remains to be shown if all genes required for competence development are present and under which conditions L. lactis would be able to become competent. With the aid of the current knowledge of other competent bacteria such as B. subtilis and Streptococcus pneumoniae, one could expect these questions to be answered soon.

The finding that several genes involved in aerobic respiration were present, including men, hemHKN, and $c y$ $t A B C D$ operons, is rather surprising. In conjunction with the notion that improved growth occurs in media containing hemin, this suggests that aerobic respiration does exist in this fermentative bacterium. Bolotin et al. (2001) describe many more interesting features related to protein secretion, cell wall metabolism, and putative horizontal gene transfer between Lactococci and certain gramnegative bacteria, which forms the start 
of novel and more directed studies of these phenomena.

The impact of the genome sequence of $L$. lactis on LAB research in general cannot easily be overestimated. Numerous basic and application-directed programs will benefit from using the sequence information, for example, via comparative and functional genomics studies using DNA microarrays or even protein arrays. A persisting issue is the use of genetically modified organisms (GMOs) in food. Especially among LAB, various GMOs with improved properties are on the shelf, but almost none are reaching the marketplace because of substantial consumer concerns. For this reason it is high time to give more and better information to the public about possible risks of GMOs in food. One of the ways to do that is to initiate specific safety-assessment programs, developing concrete tools that can identify possible side effects of genetic modification, such as increased expression of genes encoding possibly harmful proteins. The expression levels of all genes in the GMO determined by use of DNA microarrays can then be compared with the natural levels in industrial strains and to those in classically mutagenized stains. This procedure might help to win back the confidence of consumers toward GMOs, especially when possible risk factors of GMOs, for example, those posed by genes that are unusually highly expressed in the GMO, will be evaluated properly. Moreover, the observed expression levels of the genes in the genome could very well be similarly high as (or even lower than) those of wildtype or randomly mutagenized strains, showing clear advantages of the use of
GMOs. A current initiative within the European FW5 Programme coordinated by Dr. P. Renault from INRA will address this specific issue, making use of the IL1403 sequence. Also, when true foodgrade systems are used (e.g., lacking antibiotic resistance markers and using only homologous DNA [self-cloning]), this approach could eventually stimulate food production companies to bring their GMOs to market for the consumer's, and their own, benefit.

In the near future the completely annotated genome sequences of no less than five different Lactobacillus species, as well as those of $S$. thermophilus, Bifidobacterium, and Proprionibacterium species, are expected to appear in the public domain. Other strains of L. lactis, for example, those of ssp. cremoris, are being sequenced currently to allow comparative genomics with other Lactococci and LAB species. Moreover, sequencing projects are ongoing within dairy and other food-related companies; this stresses the high expectations of food biotechnology to translate results from genome mining and functional genomics efforts into valuable knowledge for application. An updated overview of microbial sequencing projects, both finished and in progress, is available at the TIGR Web site (http://www.tigr.org/tdb/ mdb/mdbcomplete.html). A comparative genomics approach of LAB also involving high-AT gram-positive pathogens, such as Streptococcus pneumoniae, could contribute to a better understanding of the factors determining the distinction between favorable characteristics on the one hand and pathogenesis on the other. The complete L. lactis IL1403 sequence is the first genomic milestone in $\mathrm{LAB}$ research and forms the starting point for further exciting developments in functional genomics research of LAB and in food biotechnology.

\section{ACKNOWLEDGMENTS}

I am grateful to Dr. Jan Kok for critical reading of this commentary.

\section{REFERENCES}

Bolotin, A., Wincker, P., Mauger, S., Jaillon, O., Malarme, K., Weissenbach, J., Ehrlich, S.D., and Sorokin, A. 2001. Genome Res. 11: 731-753.

Chopin, A., Bolotin, A., Sorokin, A., Ehrlich, S.D., and Chopin, M.C. 2001. Nucl. Acids Res. 29: 644-651.

Delcour, J., de Vuyst, L., and Shortt, C. 1999. Intl. Dairy J. (Special issue) 9: 3-80. Gasson, M.J. and de Vos, W.M. 1994. Genetics and biotechnology of lactic acid bacteria. Chapman and Hall, London.

Gilbert, C., Robinson, K., Le Page, R.W., and Wells, J.M. 2000. Infect. Immunol. 68: 3251-3260.

Konings, W.N., Kuipers, O.P., and Huis in 't Veld, J.H.J. 1999. Lactic acid bacteria: Genetics, metabolism and applications. Kluwer Academic Publishers, Dordrecht, The Netherlands.

Kuipers, O.P., Buist, G. and Kok, J. 2000. Res. Microbiol. 151: 815-822.

Kunst, F., Ogasawara, N., Moszer, I, Albertini, A. M., Alloni, G., Azevedo, V., Bertero, M.V., Bessieres, P., Bolotin, A., Borchert, S., et al. 1997. Nature 390: 249-256.

Rallu, F., Gruss, A., Ehrlich, S.D., Maguin, E. 2000. Mol. Microbiol. 35: 517-528.

Steidler, L., Hans, W., Schotte, L., Neirynck, S., Obermeier, F., Falk, W., Fiers, W., and Remaut, E. 2000. Science 289: 1352-1355.

TIGR Microbial Database. http://www. tigr.org/tdb/mdb/mdbcomplete.html 


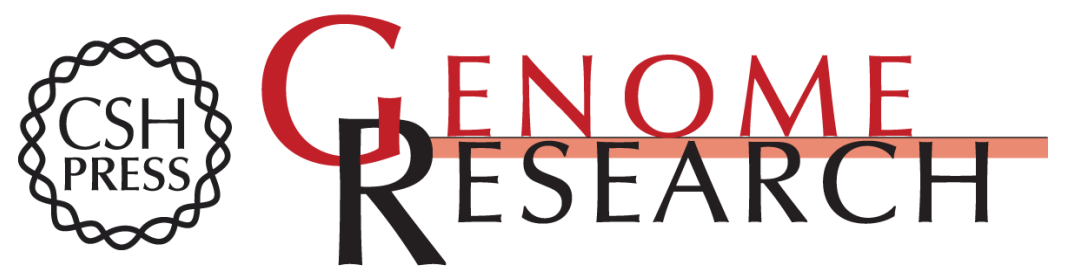

\section{Complete DNA Sequence of Lactococcus lactis Adds Flavor to Genomics}

Oscar P. Kuipers

Genome Res. 2001 11: 673-674

Access the most recent version at doi:10.1101/gr.188501

References This article cites 7 articles, 3 of which can be accessed free at: http://genome.cshlp.org/content/11/5/673.full.html\#ref-list-1

\section{License}

Email Alerting Receive free email alerts when new articles cite this article - sign up in the box at the Service top right corner of the article or click here.

\section{Affordable, Accurate Sequencing.}

To subscribe to Genome Research go to: https://genome.cshlp.org/subscriptions 